\title{
Presence of SARS-CoV-2 Transcripts in the Choroid Plexus of MS and Non-MS Patients With COVID-19
}

Vidmante Fuchs, BSc, * Michael Kutza, Cand Med, * Sven Wischnewski, Cand Med, * Nikolaus Deigendesch, MD, PhD, Luc Lutz, BSc, Laila Kulsvehagen, MSc, Gerda Ricken, MSc, Ludwig Kappos, MD, Alexandar Tzankov, MD, Simon Hametner, MD, PhD, Stephan Frank, MD, Lucas Schirmer, MD,*† and Anne-Katrin Pröbstel, MD*†

Neurol Neuroimmunol Neuroinflamm 2021;8:e957. doi:10.1212/NXI.0000000000000957

Although primarily targeting the respiratory system, coronavirus disease 2019 (COVID-19) affects the CNS in up to $80 \%$ of patients. ${ }^{1}$ Yet, findings on COVID-19 neuropathology have been conflicting: autopsy reports range from inflammatory CNS syndromes, cerebrovascular events, ${ }^{1}$ and endothelial damages ${ }^{2}$ to no COVID-19-specific brain pathologies. ${ }^{3}$ Little is known about the clinical course of neurologic autoimmune diseases and concurrent severe acute respiratory syndrome coronavirus-2 (SARS-CoV-2) infection. Limited evidence suggests no difference in the incidence of hospitalization in patients with COVID-19 with autoimmune diseases as compared to the general population. ${ }^{4,5}$ Therefore, further in-depth pathologic investigations of patients with COVID-19 with autoimmune comorbidities are needed.

MS is the most frequent autoimmune disease of the CNS with inflammatory demyelination and blood-brain barrier (BBB) disruption being typical pathologic hallmarks. ${ }^{6}$ However, whether MS renders patients more susceptible to CNS involvement during SARS-CoV-2 infection or worsens MS-related disease activity remains elusive. In this study, we performed a comprehensive histologic and spatial transcriptomic assessment of a patient with MS deceased of COVID-19-associated respiratory failure in comparison with a non-MS patient with COVID19 to address (1) whether an impaired BBB in MS facilitates viral entry to the CNS and (2) whether COVID-19-associated immune dysregulation leads to MS lesion (re)activation.

The decedent was a 67-year-old woman diagnosed with relapsing MS in 1990. Brain MRI revealed multiple white matter lesions including gadolinium-enhancing lesions in MS-typical locations. An immunomodulatory therapy with interferon beta-1b was started in 1996 and discontinued for the past 3 years. Gradual clinical worsening eventually led to the diagnosis of secondary-progressive MS with superimposed relapses. Her most recent MRI scan from 2009 showed residual disease activity with 2 gadolinium-enhancing lesions. She was initially admitted to the hospital in March 2020 for respiratory tract infection presenting with cough, intermittent fever, and dyspnea. SARS-CoV-2 infection was confirmed by nasopharyngeal swab testing, and COVID-19 was diagnosed on CT scan and accompanied by laboratory signs of systemic inflammation (elevated C-reactive protein and neutrophils) and lymphopenia. She was treated experimentally with hydroxychloroquine and cefepime for bacterial superinfection. After her denial of mechanical ventilation, she died from respiratory failure 13 days after COVID-19 onset.

\author{
Correspondence \\ Dr. Pröbstel \\ anne-katrin.proebstel@usb.ch
}



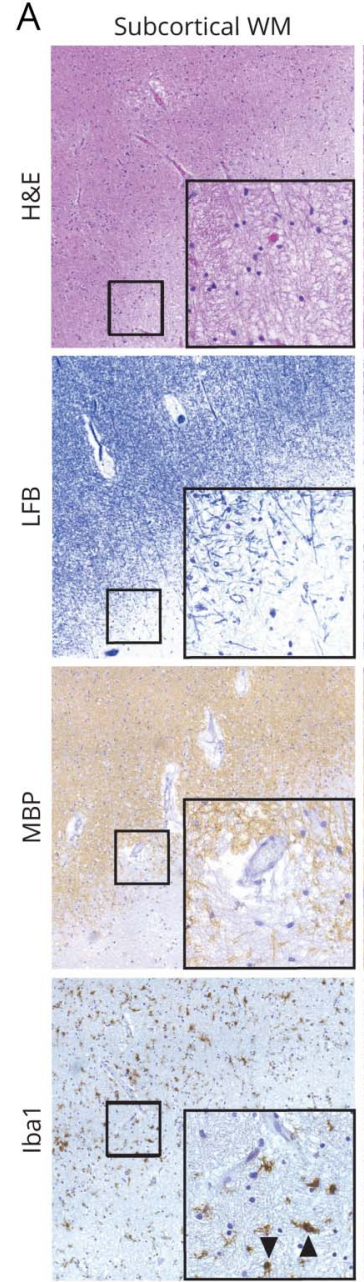

B

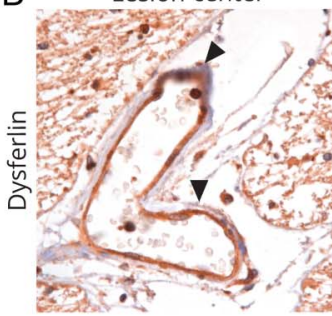

Periventricular WM
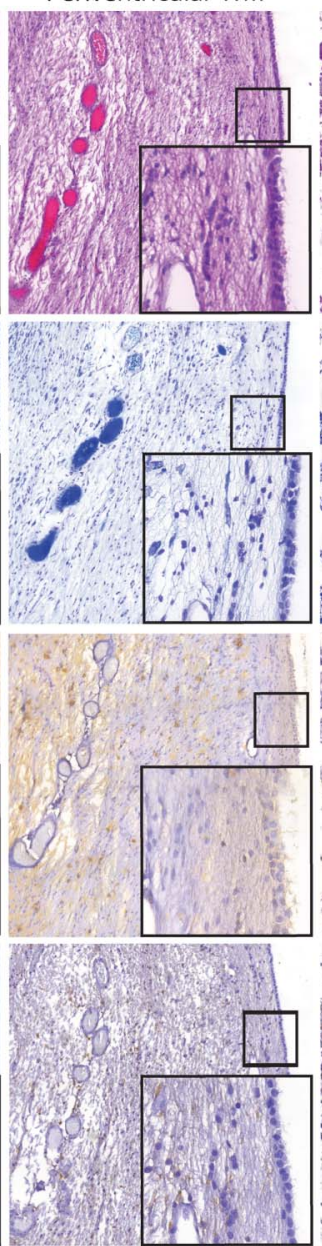

PV lesion center
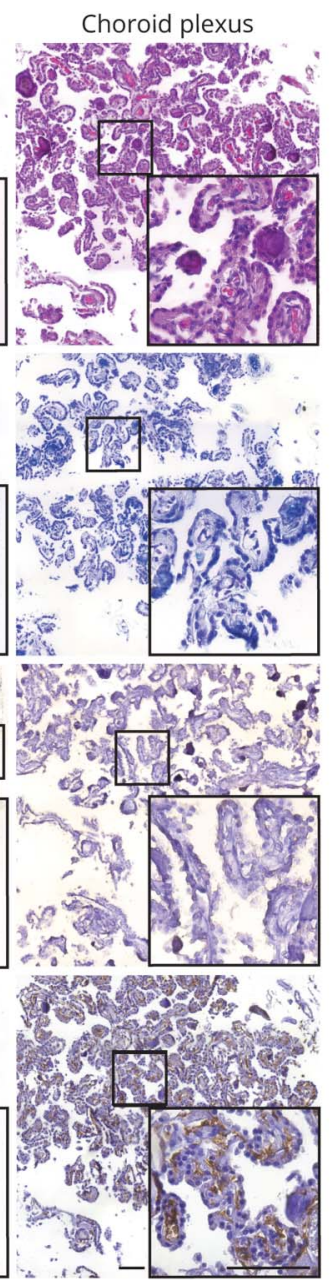

PV lesion center
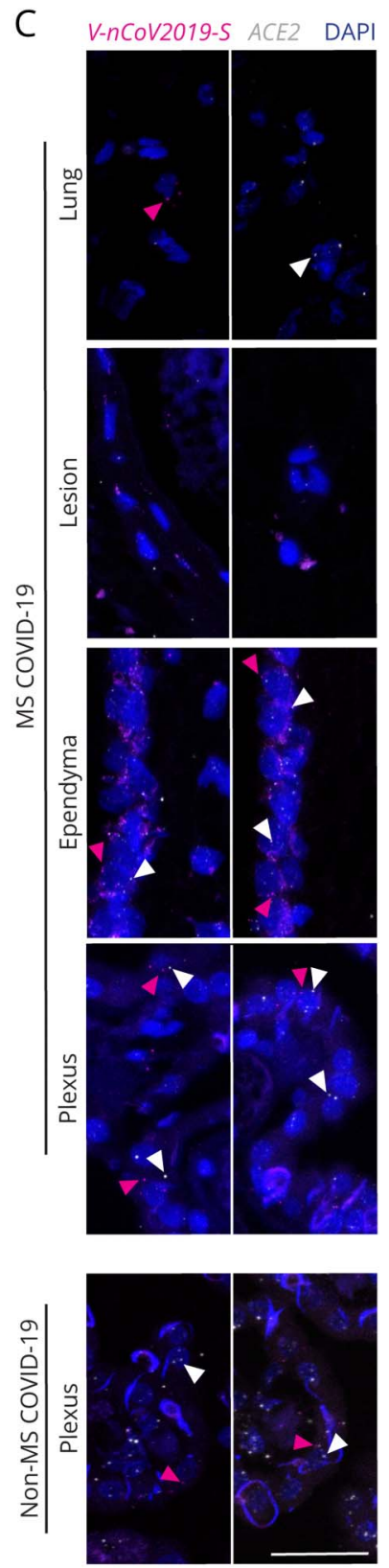

(A-B) Macroscopically visible lesions were assessed by (A) H\&E, LFB staining, and MBP, Iba1, CD45, and (B) dysferlin immunohistochemical evaluation. Given the lack of ongoing myelin phagocytosis presence of $\mathrm{Iba} 1^{+}$macrophages, all examined lesions were staged as chronic-inactive. Scale bar indicates $100 \mu \mathrm{m}$. (C) Assessing the presence and spatial distribution of severe acute respiratory syndrome coronavirus-2 (SARS-COV-2) transcripts by in situ hybridization in MS COVID-19 compared with non-COVID-19 tissue, we found presence of SARS-CoV-2 transcripts (pink arrows) in lung tissue, ependymal cells, and choroid plexus (CP) epithelial cells from MS-COVID-19 in comparable amount with non-MS COVID-19 CP epithelial cells with some coexpression of ACE2 (white arrows). Notably, SARS-CoV-2 transcripts were not present in MS lesions areas, suggesting CP epithelial cells as a key constraint of viral CNS entry. Arrows indicate positive cells. Left and right panel show different areas of the respective tissue section. Scale bar indicates $20 \mu \mathrm{m}$. COVID-19= coronavirus disease $2019 ; \mathrm{H} \& \mathrm{E}=$ hematoxylin and eosin; LFE = luxol fast blue; $\mathrm{MBP}=$ myelin basic protein; $\mathrm{PV}=$ periventricular; $\mathrm{WM}=$ white $\mathrm{matter}$.

The postmortem gross examination of the brain revealed pronounced frontotemporal atrophy and at least 12 macroscopically visible lesions at MS-typical locations. Routine histologic examination (e-methods, links.lww.com/NXI/ A402) of lesion areas revealed demyelination based on Luxol fast blue and antibody stains against myelin basic protein with relative axon preservation in lesion areas (figure 1A, figure e-1, $A$ and B, links.lww.com/NXI/A400). Based on routine hematoxylin and eosin stain, we could rule out vascular and hypoxic pathologic changes focusing on hypoxia-sensitive areas, such as the hippocampus and cerebellum (figure e-1C). To assess BBB disruption and inflammatory lesion activity, brain tissue samples were further assessed with antibodies against dysferlin, Iba1, and CD45 (figure 1, A and B, figure e-1, A and B). Dysferlin staining indicated low-grade residual BBB leakage through weak to moderate endothelial 
expression within or nearby MS lesions (figure 1B). All assessed lesions were classified as chronic inactive with low numbers of perivascular $\mathrm{CD} 45^{+}$leukocytes and only weak $\mathrm{Iba} 1^{+}$microglia activation particularly at lesion rims (figure 1A, figure e-1B). We did not find signs of active demyelination in the form of myelin phagocytosis or presence of foam cells (figure 1A, figure e-1, A and B). Hence, absence of inflammatory immune infiltrates and myelin phagocytosis confirmed that systemic SARS-CoV-2 infection did not result in MS lesion (re)activation. To complement our previous quantitative reverse transcription ( $\mathrm{qRT}$ )-PCR findings in COVID-19 demonstrating low-level presence of viral transcripts in the olfactory bulb ${ }^{3}$ (table e-2), we next assessed the presence and spatial distribution of SARS-CoV-2 RNA by multiplex in situ hybridization (ISH, e-methods). We used ISH probes targeting the $S$ gene encoding the viral spike protein and ACE2 as a viral entry target. Lung tissues from both the MS and non-MS patients with COVID-19 (figure e-1D) were used as a positive control (figure 1C, figure e-2B, links.lww.com/NXI/A401). Although no SARS$\mathrm{CoV}-2$ transcripts were present in the examined lesion areas (figure 1C), SARS-CoV-2 and ACE2 transcripts were consistently detected in epithelial cells of the choroid plexus (CP) and ependymal cells of the CSF-brain interface in both cases, often in co-presence (figure 1C, figures e-1E and e-2). Notably, SARS-CoV-2 transcripts were regularly found in lung tissues in conjunction with $A C E 2$ transcripts in the same cells (figure 1C, figure e-2B). In summary, we found no direct evidence for neuronal or glial cell infection neither in healthy nor demyelinated areas (figure 1C, figure e-2A) despite evidence for residual BBB leakage in MS COVID-19 (figure 1B).

The differential detection of viral transcripts in the $\mathrm{CP}$, but its absence in the brain parenchyma suggests that the BBB is a key restraint of viral entry into the CNS (figure-1E, links.lww. com/NXI/A400). This is in line with recent data examining the SARS-CoV-2 infection route in brain organoids indicating that the $\mathrm{CP}$ as a prime CNS entry site. ${ }^{7}$ Furthermore, damage of the BBB itself is an alternative CNS entry point, and, indeed, endothelial damage has been reported in COVID-19 neuropathology. ${ }^{2}$ However, in our case, although we observed some focal signs of BBB leakage, we did not detect SARS-CoV2 RNA in MS lesion and adjacent normal-appearing tissue areas by in situ assessment. The absence of viral RNA in the brain parenchyma, yet positive qRT-PCR results from the nasopharyngeal swab and olfactory bulb, could be indicative of previous CNS clearance because the deceased patient was in the late/postinfectious stage of COVID-19. Indeed, signs of viral clearance at autopsy were seen in the corresponding lung tissue showing low transcript load both by spatial transcriptomic assessment (figure 1C) and by qRT-PCR (table e-2, links.lww.com/NXI/A402).

Although this is a single case of a COVID-19-affected patient with a long-standing history of progressive MS, our findings provide no evidence for MS disease exacerbation or lesion

(re)activation. These results are in line with recent clinical studies on stable disease in patients with COVID-19 with other autoimmune diseases. ${ }^{4,5}$ Importantly, our study highlights the significance of CNS barriers, such as the CP, as a critical entry point for SARS-CoV-2 and calls for further studies to provide more insight into the underlying mechanisms. Because our study reports on a chronic disease course, future studies will need to shed light on SARS$\mathrm{CoV}-2$-associated pathologies in patients with active disease activity in MS and other underlying autoimmune CNS diseases.

\section{Study Funding}

Supported by the Swiss-European Mobility Programme (to V. Fuchs), the Medical Faculty Mannheim, Heidelberg University (student fellowship, to S. Wischnewski), the Hertie Foundation (student fellowship, to M. Kutza; medMS MyLab program, P1180016, to L. Schirmer), intramural funding from the Amsterdam University (Award for academic excellence studying abroad to L. Kulsvehagen), the Botnar Research Center for Child Health (to A. Tzankov), the German Research Foundation (DFG project number 433081111, to L. Schirmer), the National Multiple Sclerosis Society (FG-190233617, to L. Schirmer; Kathleen C. Moore Fellowship: FG1708-28871, to A.-K. Pröbstel), and intramural funding from the University of Basel (to A.-K. Pröbstel).

\section{Disclosure}

The authors have nothing to disclose in regards to this study. Go to Neurology.org/NN for full disclosures.

\section{Publication History}

Received by Neurology: Neuroimmunology \& Neuroinflammation September 7, 2020. Accepted in final form November 19, 2020.

\section{Appendix Authors}

\begin{tabular}{lll}
\hline Name & Location & Contribution \\
\hline $\begin{array}{l}\text { Vidmante } \\
\text { Fuchs, BSc }\end{array}$ & $\begin{array}{l}\text { University of Basel, } \\
\text { Switzerland }\end{array}$ & $\begin{array}{l}\text { Designed and conceptualized the } \\
\text { study, major role in data } \\
\text { acquisition and interpretation, } \\
\text { major role in imaging, major role } \\
\text { in figure design, and drafted the } \\
\end{array}$ \\
& $\begin{array}{l}\text { manuscript for intellectual } \\
\text { content }\end{array}$
\end{tabular}

\begin{tabular}{lll}
\hline $\begin{array}{l}\text { Michael } \\
\text { Kutza, Cand } \\
\text { Med }\end{array}$ & $\begin{array}{l}\text { Heidelberg } \\
\text { University, } \\
\text { Mannheim, } \\
\text { Germany }\end{array}$ & $\begin{array}{l}\text { Designed and conceptualized the } \\
\text { study, major role in data } \\
\text { acquisition and interpretation, } \\
\text { major role in imaging, major role } \\
\text { in figure design, and drafted the } \\
\text { manuscript for intellectual } \\
\text { content }\end{array}$ \\
$\begin{array}{l}\text { Sven } \\
\text { Wischnewski, } \\
\text { Cand Med }\end{array}$ & $\begin{array}{l}\text { University, } \\
\text { Mannheim, } \\
\text { Germany }\end{array}$ & $\begin{array}{l}\text { Designed and conceptualized the } \\
\text { study, major role in data } \\
\text { acquisition and interpretation, } \\
\text { major role in imaging, major role } \\
\text { in figure design, and drafted the } \\
\text { manuscript for intellectual }\end{array}$ \\
& & content \\
\hline
\end{tabular}


Appendix (continued)

\begin{tabular}{|c|c|c|}
\hline Name & Location & Contribution \\
\hline $\begin{array}{l}\text { Nikolaus } \\
\text { Deigendesch, } \\
\text { MD, PhD }\end{array}$ & $\begin{array}{l}\text { University of Basel, } \\
\text { Switzerland }\end{array}$ & $\begin{array}{l}\text { Patient tissue acquisition, data } \\
\text { interpretation, and revised the } \\
\text { manuscript for intellectual } \\
\text { content }\end{array}$ \\
\hline Luc Lutz, BSc & $\begin{array}{l}\text { University of Basel, } \\
\text { Switzerland }\end{array}$ & $\begin{array}{l}\text { Clinical data management and } \\
\text { drafted the manuscript for } \\
\text { intellectual content }\end{array}$ \\
\hline $\begin{array}{l}\text { Laila } \\
\text { Kulsvehagen, } \\
\text { MSc }\end{array}$ & $\begin{array}{l}\text { University of Basel, } \\
\text { Switzerland }\end{array}$ & $\begin{array}{l}\text { Helped with figure design and } \\
\text { drafted the manuscript for } \\
\text { intellectual content }\end{array}$ \\
\hline $\begin{array}{l}\text { Gerda Ricken, } \\
\text { MSc }\end{array}$ & $\begin{array}{l}\text { Medical University } \\
\text { Vienna, Austra }\end{array}$ & $\begin{array}{l}\text { Data aquisition, imaging, and } \\
\text { revised the manuscript for } \\
\text { intellectual content }\end{array}$ \\
\hline $\begin{array}{l}\text { Ludwig } \\
\text { Kappos, MD }\end{array}$ & $\begin{array}{l}\text { University of Basel, } \\
\text { Switzerland }\end{array}$ & $\begin{array}{l}\text { Clinical care of the patient and } \\
\text { revised the manuscript for } \\
\text { intellectual content }\end{array}$ \\
\hline $\begin{array}{l}\text { Alexandar } \\
\text { Tzankov, MD }\end{array}$ & $\begin{array}{l}\text { University of Basel, } \\
\text { Switzerland }\end{array}$ & $\begin{array}{l}\text { Patient tissue acquisition and } \\
\text { revised the manuscript for } \\
\text { intellectual content }\end{array}$ \\
\hline $\begin{array}{l}\text { Simon } \\
\text { Hametner, } \\
\text { MD, PhD }\end{array}$ & $\begin{array}{l}\text { Medical University } \\
\text { Vienna, Austria }\end{array}$ & $\begin{array}{l}\text { Data acquisition, imaging, data } \\
\text { interpretation, and revised the } \\
\text { manuscript for intellectual } \\
\text { content }\end{array}$ \\
\hline $\begin{array}{l}\text { Stephan } \\
\text { Frank, MD }\end{array}$ & $\begin{array}{l}\text { University of Basel, } \\
\text { Switzerland }\end{array}$ & $\begin{array}{l}\text { Patient tissue acquisition and } \\
\text { revised the manuscript for } \\
\text { intellectual content }\end{array}$ \\
\hline
\end{tabular}

Appendix (continued)

\begin{tabular}{lll}
\hline Name & Location & Contribution \\
\hline $\begin{array}{l}\text { Lucas } \\
\text { Schirmer, MD }\end{array}$ & $\begin{array}{l}\text { Heidelberg } \\
\text { University, } \\
\text { Mannheim, } \\
\text { Germany }\end{array}$ & $\begin{array}{l}\text { Designed and conceptualized the } \\
\text { study, data interpretation, figure } \\
\text { design, and drafted the } \\
\text { manuscript for intellectual } \\
\text { content }\end{array}$ \\
\hline $\begin{array}{l}\text { Anne-Katrin } \\
\text { Pröbstel, MD }\end{array}$ & $\begin{array}{l}\text { University of Basel, } \\
\text { Switzerland }\end{array}$ & $\begin{array}{l}\text { Designed and conceptualized the } \\
\text { study, patient tissue aquisition, } \\
\text { data interpretation, clinical data } \\
\text { management, figure design, amd } \\
\text { drafted the manuscript for } \\
\text { intellectual content }\end{array}$ \\
& &
\end{tabular}

\section{References}

1. Paterson RW, Brown RL, Benjamin L, et al. The emerging spectrum of COVID-19 neurology: clinical, radiological and laboratory findings. Brain 2020;143: $3104-3120$

2. Jaunmuktane Z, Mahadeva U, Green A, et al. Microvascular injury and hypoxic damage: emerging neuropathological signatures in COVID-19. Acta Neuropathol 2020;140:397-400.

3. Deigendesch N, Sironi L, Kutza M, et al. Correlates of critical illness-related en cephalopathy predominate postmortem COVID-19 neuropathology. Acta Neuropathol 2020;140:583-586.

4. Sormani MP; Italian Study Group on C-iims. An Italian programme for COVID-19 infection in multiple sclerosis. Lancet Neurol 2020;19:481-482.

5. Haberman R, Axelrad J, Chen A, et al. Covid-19 in immune-mediated inflammatory diseases_case series from New York. N Engl J Med 2020;383:85-88.

6. Reich DS, Lucchinetti CF, Calabresi PA. Multiple sclerosis. N Engl J Med 2018;378: 169-180.

7. Pellegrini L, Albecka A, Mallery DL, et al. SARS-CoV-2 infects the brain choroid plexus and disrupts the blood-CSF-barrier in human brain organoid models. Cell Stem Cell 2020;27:951-961.e5. 


\title{
Neurology \\ Neuroimmunology \& Neuroinflammation
}

\author{
Presence of SARS-CoV-2 Transcripts in the Choroid Plexus of MS and Non-MS \\ Patients With COVID-19 \\ Vidmante Fuchs, Michael Kutza, Sven Wischnewski, et al. \\ Neurol Neuroimmunol Neuroinflamm 2021;8; \\ DOI 10.1212/NXI.0000000000000957
}

This information is current as of January 27, 2021

\section{Updated Information \& Services}

References

Citations

Subspecialty Collections

Permissions \& Licensing

Reprints including high resolution figures, can be found at: http://nn.neurology.org/content/8/2/e957.full.html

This article cites 7 articles, 0 of which you can access for free at: http://nn.neurology.org/content/8/2/e957.full.html\#\#ref-list-1

This article has been cited by 2 HighWire-hosted articles: http://nn.neurology.org/content/8/2/e957.full.html\#\#otherarticles

This article, along with others on similar topics, appears in the following collection(s):

Autoimmune diseases

http://nn.neurology.org//cgi/collection/autoimmune_diseases COVID-19

http://nn.neurology.org//cgi/collection/covid_19

Multiple sclerosis

http://nn.neurology.org//cgi/collection/multiple_sclerosis

Information about reproducing this article in parts (figures,tables) or in its entirety can be found online at:

http://nn.neurology.org/misc/about.xhtml\#permissions

Information about ordering reprints can be found online: http://nn.neurology.org/misc/addir.xhtml\#reprintsus

Neurol Neuroimmunol Neuroinflamm is an official journal of the American Academy of Neurology.

Published since April 2014, it is an open-access, online-only, continuous publication journal. Copyright Copyright (C) 2021 The Author(s). Published by Wolters Kluwer Health, Inc. on behalf of the American Academy of Neurology.. All rights reserved. Online ISSN: 2332-7812.

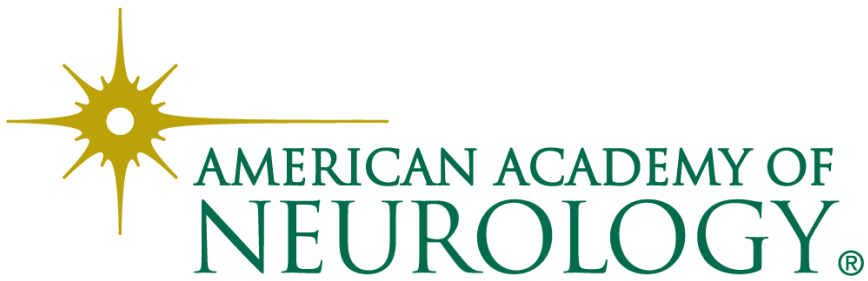

